\title{
Acute aortic dissection type A discloses Corpus alienum
} Aron Frederik Popov*1, Mersa Mohammed Baryalei ${ }^{1}$, Jan Dieter Schmitto ${ }^{1}$, Jose Hinz ${ }^{2}$, Christoph Hermann Wiese ${ }^{2}$, Björn Raab' ${ }^{3}$, Philipp Kolat ${ }^{1}$, Friedrich Albert Schoendube ${ }^{1}$ and Ralf Seipelt ${ }^{1}$

\author{
Address: ${ }^{1}$ Department of Thoracic and Cardiovascular Surgery, University of Göttingen, Germany, ${ }^{2}$ Department of Anaesthesiology, Emergency \\ and Intensive Care Medicine, University of Göttingen, Germany and ${ }^{3}$ Department of Radiology, University of Göttingen, Germany \\ Email: Aron Frederik Popov* - Popov@med.uni-goettingen.de; Mersa Mohammed Baryalei - Baryalei@med.uni-goettingen.de; \\ Jan Dieter Schmitto - Schmitto@med.uni-goettingen.de; Jose Hinz - mail@josehinz.de; Christoph Hermann Wiese - cwiese@med.uni- \\ goettingen.de; Björn Raab - bwraab@med.uni-goettingen.de; Philipp Kolat - syrakus@gmx.de; \\ Friedrich Albert Schoendube - Schondube@med.uni-goettingen.de; Ralf Seipelt - rseipelt@med.uni-goettingen.de \\ * Corresponding author
}

Published: 2 January 2009

Received: 25 November 2008

Journal of Cardiothoracic Surgery 2009, 4:I doi:10.1186/1749-8090-4-I

Accepted: 2 January 2009

This article is available from: http://www.cardiothoracicsurgery.org/content/4/I/I

(c) 2009 Popov et al; licensee BioMed Central Ltd.

This is an Open Access article distributed under the terms of the Creative Commons Attribution License (http://creativecommons.org/licenses/by/2.0), which permits unrestricted use, distribution, and reproduction in any medium, provided the original work is properly cited.

\begin{abstract}
We report an unusual case of an aortic type $A$ dissection with a corpus alienum which compresses the right ventricle. The patient successfully underwent an aortic root replacement in deep hypothermia with re-implantation of the coronary arteries using a modified Bentall procedure and the resection of the corpus alienum. Intraoperative finding reveals 3 greatly adhered gauze compresses, which were most likely forgotten in the operation 34 years ago.
\end{abstract}

\section{Case presentation}

A 64-year-old patient was referred to us from another hospital with symptoms of angina pectoris and suspicion of constrictive pericarditis. An acute myocardial infarction had already been ruled out. Further diagnostic measures were carried out in our hospital. Due to increasing pain and hemodynamic instability, a thorax computed tomography (CT) with contrast medium was performed. This revealed a type A dissection with suspicion of a bloody pericardial effusion (Figures 1, 2 and 3). The patient had been healthy up to this day, only in 1974 at the age of 30 , an ASD closure had been carried out via lateral thoracotomy for an atrial septum defect. The operation was carried out at another institution and postoperative course was uneventful.

The emergency operation was initiated immediately after the diagnosis was made. The patient was connected to the heart-lung machine via the groin. A sternotomy was performed, revealing an adherent purulent structure (Figure 4), approximately $4-5 \mathrm{~cm}$ dimension that was clearly compressing the right ventricle without pericardial effusion, located in close relation to the ascending aorta. After cautious dissection, 3 greatly adhered gauze compresses (Figure 5) were carefully removed from the pericardium. These were most likely forgotten in the operation 34 years ago. Due to this finding, the emergency surgery was aborted due to the infectious process.

The patient was transferred to the intensive care ward and discharged on the 10th postoperative day without treatment of the type A dissection. Postoperative microbiological tests showed no indication of bacterial colonization. During the hospital stay we started an antihypertensive therapy. However, after the first operation at our institute the patient wanted time to think it over concerning the 


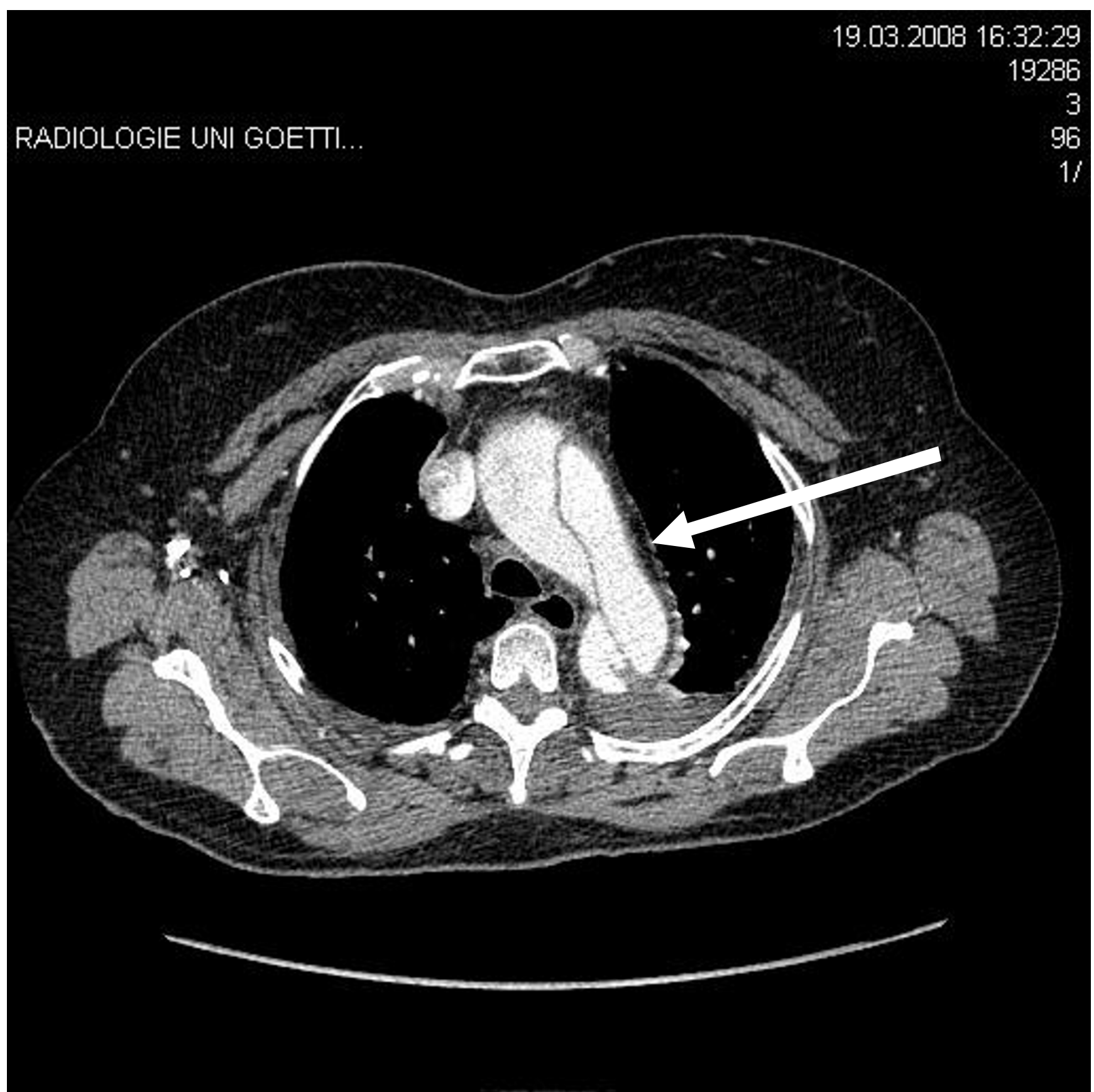

\section{Figure I}

CT-scan showing type A dissection with a dissection flap.

forthcoming high-risk operation. Although we insistently informed the patient about the dangerous situation, she contacted us not until five weeks with the decision that we can perform the operation.

The patient was rescheduled six weeks later after the first operation at our institute to repeat the CT-scan. This showed a progression of the type A dissection with renewed hemorrhagic pleural effusion followed by promptly surgical treatment.

Connection to the heart-lung machine was again through the groin and the thorax was reopened again. An aortic root replacement in deep hypothermia with re-implantation of the coronary arteries using a modified Bentall procedure was carried out. The aortic valve was replaced by a 


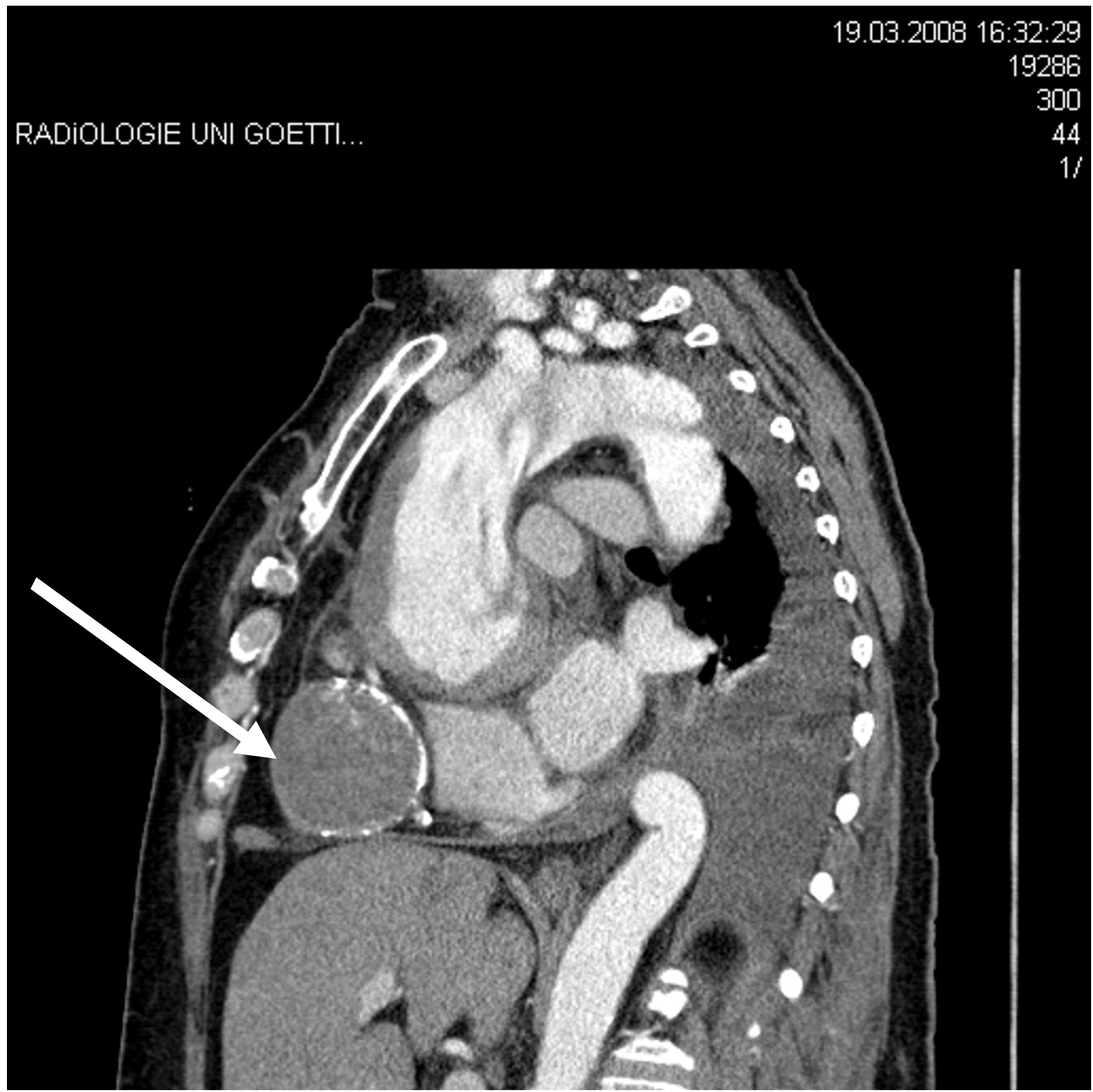

Figure 2

CT scan showing an adherent structure which compressing the right ventricle.

Medtronic Stentless Freestyle bioprosthesis. The supraaortic vessels were re-implanted and the ascendeing aorta and aortic arch were replaced with a Hemashield-prosthesis. The postoperative course was unremarkable and the patient was discharged after 14 days. A follow-up CT-scan was carried out one month later that documented a continued good postoperative result with a decompressed right ventricle (Figures 6 and 7 ). The patient is free of pain and able to function well in daily life.

\section{Discussion}

Acute type A aortic dissection is a catastrophic disease that requires immediate surgical intervention. The main goal of surgery in acute type A aortic dissection is to prevent death from intrapericardial hemorrhage by resecting and replacing the diseased aorta with a graft [1]. Aggressive surgical approach involving extensive resection of dissected aorta for patients with aortic dissection became more popular over the recent years [2]. However, in this 


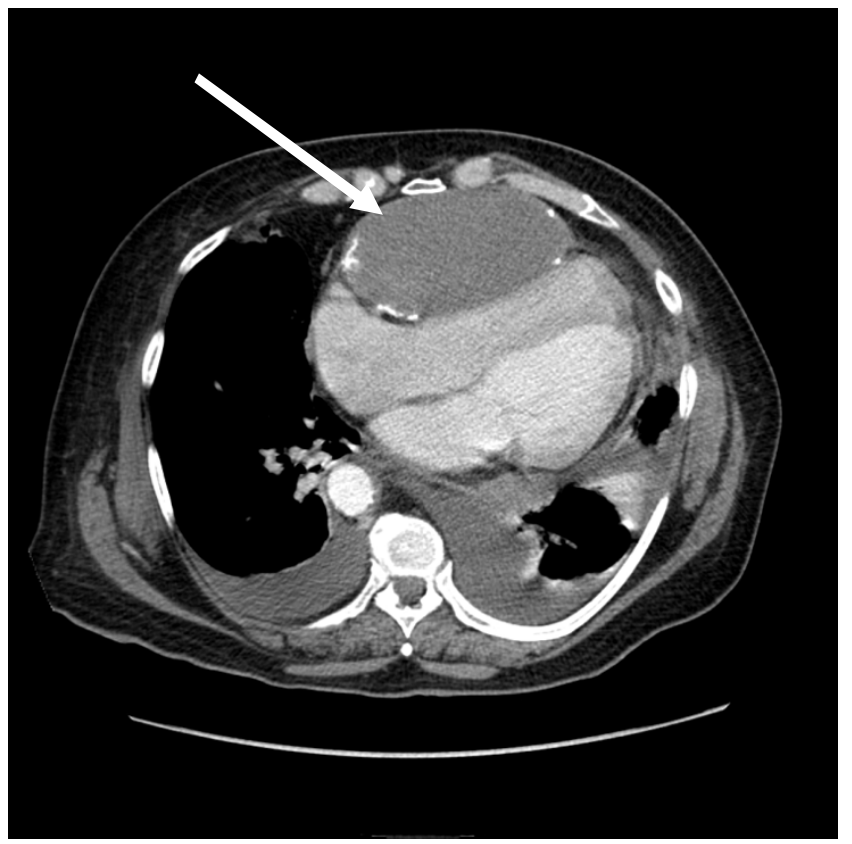

Figure 3

CT scan showing an adherent structure which compressing the right ventricle.

case the surgical treatment was deferred, because the adhered gauze compresses was to be suspected infectious process. Moreover, it is well known that infections involving ascending aortic grafts are extremely difficult to eradicate and are frequently lethal [3]. Treatment of this complication remains a challenge for surgeons, and chances of a successful outcome are considered low. Mortality rates range from $25 \%$ to $75 \%$, and morbidity in sur-

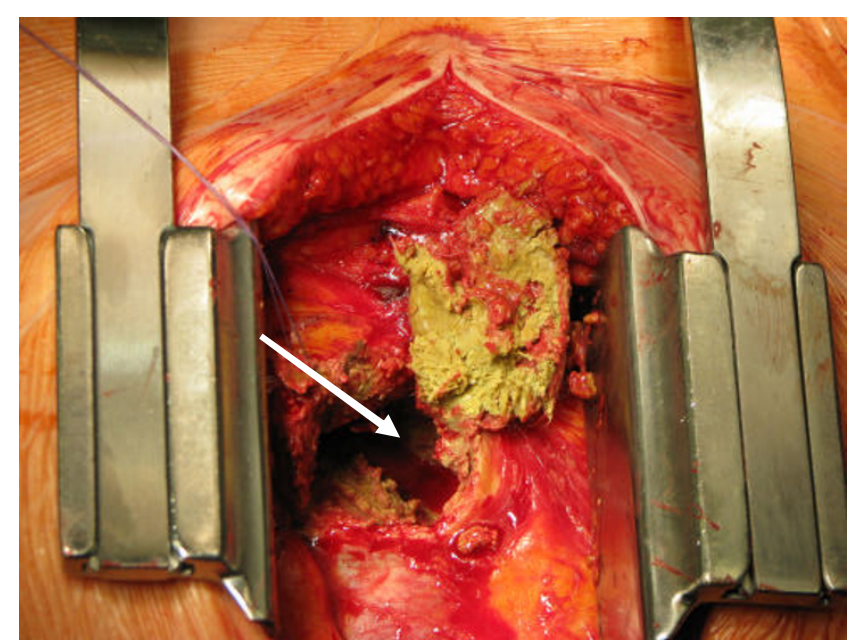

Figure 4

Intraoperative view of the opened pericardium with purulent structure.

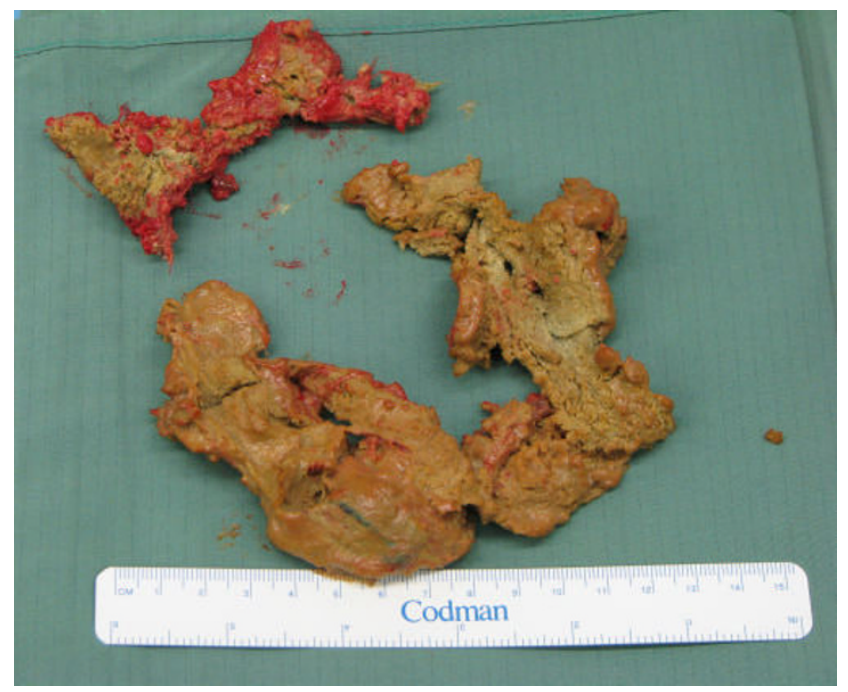

Figure 5

Three gauze compresses which were secured.

viving patients is high [4]. Several groups currently favour replacing infected ascending aortic prostheses with cryopreserved aortic homografts [4-7]. Retrospective data have suggested that, compared with using synthetic grafts, using cryopreserved homografts for treating vascular infections is associated with improved outcomes, including better elimination of infection, fewer postoperative

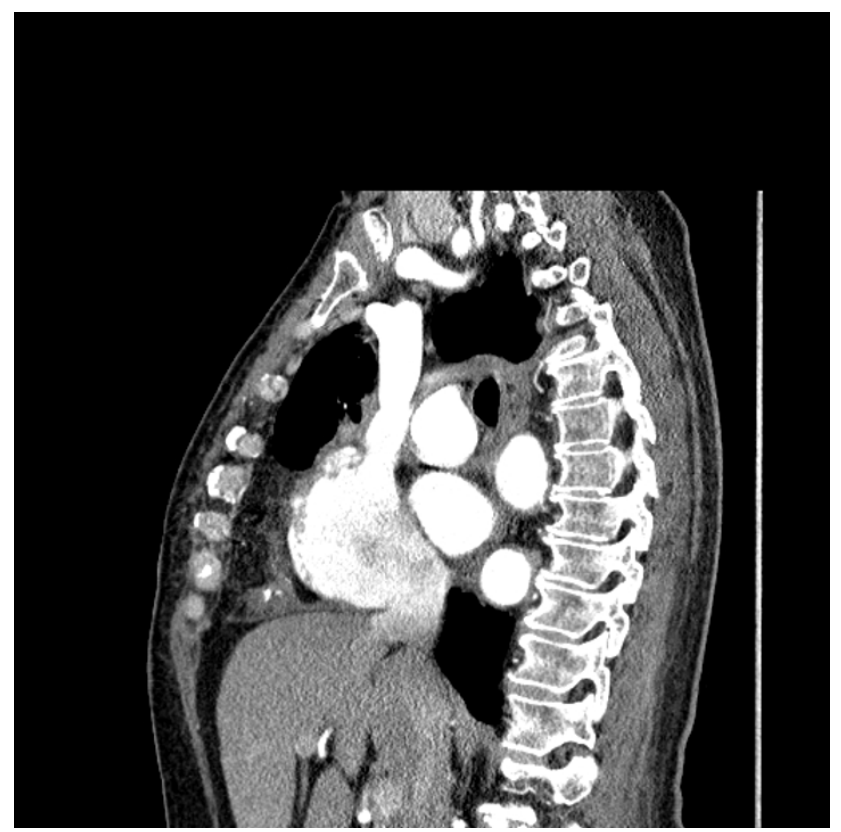

Figure 6

Follow-up CT-scan after one month with a decompressed right ventricle. 


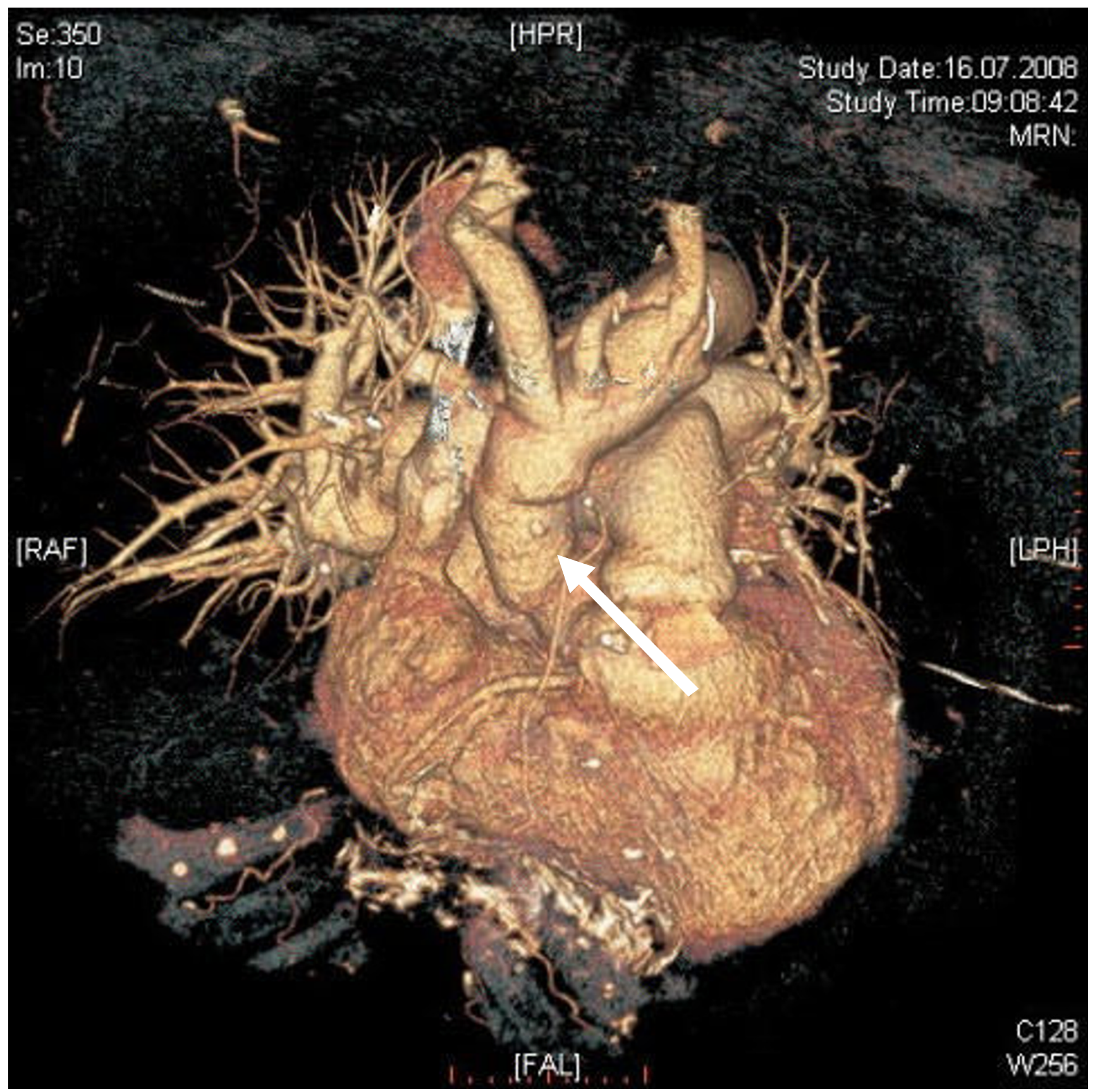

Figure 7

Three-dimensional volume rendered image showing the postoperative result after one month.

complications, and longer disease-related survival [8]. However, one commonly cited disadvantage of using homografts is their predisposition to progressive deterioration and ultimate need for re-replacement $[9,10]$. Unfortunately, in many cases, a single homograft will not reach the distal ascending aorta or transverse arch [7]. Extensive aortic replacement can be accomplished by using total arch homografts, but these are rarely available
[11]. Another treatment strategy to prevent recurrent infection is using a pedicled omental or muscle flap. Omentum is particularly popular because, in patients who have not had previous abdominal surgery, omentum can be easily accessed by extending the sternotomy incision into the abdomen for a short distance [12-16]. The blood supply to the omentum is preserved by basing the pedicle on the right gastroepiploic artery. In addition to 
filling dead space, the vascularised omental pedicle improves oxygen supply to the region, enhances immunologic response, increases antibiotic delivery, and absorbs wound secretions that can serve as substrates for bacterial growth $[13,16]$.

There are, however, many established options for managing the infected graft, but the literature on surgical treatment of ascending aortic graft infection fails to provide even the lowest level of evidence on which to base a concrete recommendation. Otherwise, the patient was not septic on admission. However, at that point of time the intraoperative situation was not clear concerning the potential infection, we decided in this special case to abort the emergency operation.

\section{Conclusion}

Delayed surgical treatment could be an acceptable alternative to prompt intervention in aortic dissection, provided a stable clinical condition can be achieved with conservative management consisting of rest, careful monitoring and periodic reassessment, if other conditions make the immediate operation very dangerous.

\section{Consent}

Written informed consent was obtained from the patient for publication of this case report and any accompanying images. A copy of the written consent is available for review by the Editor-in-Chief of this journal.

\section{Competing interests}

The authors declare that they have no competing interests.

\section{Authors' contributions}

$\mathrm{AP}, \mathrm{MB}, \mathrm{RS}$, JS and PK are members of surgical teams. CW and $\mathrm{JH}$ were the anaesthetists involved in theatre and in intensive care unit. BR was the radiologist. FS co-wrote the manuscript and added important comments to the paper. All authors have read and approved the final manuscript.

\section{References}

I. Ehrlich MP, Ergin MA, McCullough JN, Lansman SL, Galla JD, Bodian CA, Apaydin A, Griepp RB: Results of immediate surgical treatment of all acute type A dissections. Circulation 2000, 102:248-52.

2. Nienaber CA, Eagle KA: Aortic dissection: new frontiers in diagnosis and management: Part II: therapeutic management and follow-up. Circulation 2003, I 2(108):772-8.

3. Darouiche $R$ : Treatment of infections associated with surgical implants. N Engl J Med 2004, 350: I422-9.

4. Coselli JS, Koksoy C, LeMaire SA: Management of thoracic aortic graft infections. Ann Thorac Surg 1999, 67:1990-3.

5. Gott VL, Cameron DE, Alejo DE, Greene PS, Shake JG, Caparrelli DJ, Dietz HC: Aortic root replacement in 27 I Marfan patients: a 24-year experience. Ann Thorac Surg 2002, 73:438-43.

6. Vogt PR, Brunner-LaRocca HP, Lachat M, Ruef C, Turina MI: Technical details with the use of cryopreserved arterial allografts for aortic infection: influence on early and midterm mortality. J Vasc Surg 2002, 35:80-6.

7. Lytle BW, Sabik JF, Blackstone EH, Svensson LG, Pettersson GB, Cosgrove DM III: Reoperative cryopreserved root and ascending aorta replacement for acute aortic prosthetic valve endocarditis. Ann Thorac Surg 2002, 74:1754-7.

8. Vogt PR, Brunner-La Rocca HP, Carrel T, von Segesser LK, Ruef C, Debatin J, Seifert B, Kiowski W, Turina MI: Cryopreserved arterial allografts in the treatment of major vascular infection: a comparison with conventional surgical techniques. J Thorac Cardiovasc Surg 1998, I I 6:965-72.

9. Hagl C, Galla JD, Lansman SL, Fink D, Bodian CA, Spielvogel D, Griepp RB: Replacing the ascending aorta and aortic valve for acute prosthetic valve endocarditis: is using prosthetic material contraindicated? Ann Thorac Surg 2002, 74: $178 \mid-5$.

10. Kaya A, Schepens MA, Morshuis WJ, Heijmen RH, Brutel de la Riviere $A$, Dossche KM: Valve-related events after aortic root replacement with cryopreserved aortic homografts. Ann Thorac Surg 2005, 79:|49|-5.

II. Abad C, Hurle A, Feijoo J, Gomez-Marrero J, Abdallah A: Total aortic arch replacement by a cryopreserved aortic homograft. Eur J Cardiothorac Surg 1995, 9:531-3.

12. Hargrove C III, Edmunds LH Jr: Management of infected thoracic aortic prosthetic grafts. Ann Thorac Surg 1984, 37:72-7.

13. Miller DW Jr, Johnson DD: Omental pedicle graft in the management of infected ascending aortic prostheses. Ann Thorac Surg 1987, 44:6I4-7.

14. Takano T, Fukaya Y, Nakano H, Kuroda H, Amano J: Combined therapies for composite graft infection after Bentall's procedure. Ann Thorac Surg 1998, 66:564-6.

15. LeMaire SA, DiBardino DJ, Köksoy C, Coselli JS: Proximal aortic reoperations in patients with composite valve grafts. Ann Thorac Surg 2002, 74: 1777-80.

16. Luciani N, Lapenna E, De Bonis M, Possati GF: Mediastinitis following graft replacement of the ascending aorta: conservative approach by omental transposition. Eur J Cardiothorac Surg 200 I, 20:418-20.

Publish with Bio Med Central and every scientist can read your work free of charge

"BioMed Central will be the most significant development for disseminating the results of biomedical research in our lifetime. "

Sir Paul Nurse, Cancer Research UK

Your research papers will be:

- available free of charge to the entire biomedical community

- peer reviewed and published immediately upon acceptance

- cited in PubMed and archived on PubMed Central

- yours - you keep the copyright

Submit your manuscript here:

http://www.biomedcentral.com/info/publishing_adv.asp
BioMedcentral 